\title{
PKLR NM_000298.5:c.1436G>A
}

National Cancer Institute

\section{Source}

National Cancer Institute. PKLR NM 000298.5:C.1436G>A. NCI Thesaurus. Code

C158051.

A nucleotide substitution at position 1436 of the coding sequence of the PKLR gene where guanine has been mutated to adenine. 